DOI: 10.1515/auseur-2016-0028

\title{
Hungarians from Transylvania in Soviet Captivity between 1945 and 1953
}

\section{- Lectures, Exhibitions at Sapientia University -}

With the occasion of the memorial year of the Political Prisoners and Forced Labourers Deported to the Soviet Union, between April 2016 and February 2017, there are organized presentation series at Sapientia Hungarian University of Transylvania, Faculty of Sciences and Arts. The A Magyarok szovjet fogságban 1944 és 1953 között (Hungarians from Transylvania in Soviet Captivity between 1945 and 1953) titled presentation series' theme is about the civil population deported to the Soviet Gulags after the Second World War. According to the estimations, more than 200,000 Hungarian civilians were affected by this catastrophical event. Among them, more than 5,000 people were taken from ClujNapoca with the march of the Red Army units. More than a third of the prisoners perished in the several years of captivity.

Prestigious foreign and Transylvanian lecturers talk about the Hungarian captives forced into labour camps by the Soviet Union, the experience of the road to the camps, the life in the Gulags. The presentation series is open to everyone interested in this subject, and not just historians and students can get a glimpse at the Gulag world.

The Soviet imprisonment was a taboo subject in the years of communism. Generations grew up without knowing anything about the deportation of civilians to the Soviet Union. The presentation series' main purpose is to enlighten the general public about the deported Hungarians in 1944-1945 in the Soviet Gulag camps, bringing back history into the collective memory of the people.

The first lecture, entitled Emlékezet és megemlékezés. Erdélyi magyar civilek szovjet fogságban 1944 és 1953 között (Rememberence and Commemoration. Transylvanian Hungarians in Soviet Imprisonment between 1944 and 1953), was held by János Kristóf Murádin, PhD, historian, Assistant Professor at the Faculty of Sciences and Arts of Sapientia Hungarian University of Transylvania, on $11^{\text {th }}$ May 2016. The lecturer presented the waves of the Soviet deportation after the Second World War, the way the prisoners were transported to the camps, and the route to the Soviet Gulags. Memoirs of the prisoners were read, illustrating the whole story with statistics of the prisoners who died or came back alive from the camps. 
The second lecture, entitled Civilek elhurcolása Magyarországról a Szovjetunióba (Deportation of the Civilians from Hungary to the Soviet Union), was held by Tamás Stark, PhD, historian at the Hungarian Academy of Sciences, Research Centre for the Humanities, Institute of History, on $26^{\text {th }}$ May 2016. The public showed great interest in this subject and the lecture began with a reverence to the memory of all the prisoners. The presentation illustrated the main reasons the Hungarians were deported from their country. He also highlighted the importance of the prisoners in the Soviet economy and the political reasons of Moscow, eliminating those classes that did not fit into the Soviet plans. This is supported by the fact that so many people died in the camps. Tamás Stark exposed the idea that civilians in Hungary were deported in three waves. The first were war prisoners, the second wave were German people, but also Hungarians with German names were taken with them. Hungarians from Subcarpathia were deported with the purpose of 'ethnic cleansing' in the territory. An important number of Hungarian civilians arrived at the Gulags under the name of political prisoners, but they were just serving in a youth preparation programme for the protection of the country. According to Tamás Stark, from a number of 600,000 prisoners, 200,000 never returned home.

The next presentation was held by György Dupka, PhD, Secretary of Memorial Park from Szolyva (Svaliava, Ukraine), with the title of $A$ kárpátaljai magyarok 'malenkij robotra' hurcolása a GUPVI-GULÁG munkatáborokba az erôszakos szovjetizálás idején (1944-1953) és a lágerekben elhunytak emlékének megörökítése (The Deportation of the Subcarpathian Hungarians to 'Malenkaya Rabota' in GUPVI-GULAG Labour Camps in the Period of Forced Sovietization (1944-1953) and the Preservation of the Memory of Those Who Passed Away in Captivity), on $16^{\text {th }}$ June 2016. The lecturer presented the repercussions of the Soviet Union in the defeated territories and all the actions that the communist formation did to change the population integrity, mentality in the name of the communist ideology. György Dupka also highlighted the idea that it was important to have memorial sites in order to commemorate all those people who disappeared, suffered, and died in unfair circumstances.

The lecture entitled Magyar civilek internálása 1944 öszén Romániában. A Barcaföldvári haláltábor a kollektív emlékezetben (Hungarian Civilians' Relocation in the Autumn of 1944 in Romania. The Death Camp from Feldioara in the Collective Memory) was held on $17^{\text {th }}$ August. At the beginning of his presentation, historian Levente Benkő recalled that 'There is no collective sinfulness! The happenings have original authors, principals, the culprits are not a community, they are individuals, who can be identified and named, and the happenings have no connection with the present.'

Zalán Bognár, PhD, Senior Lecturer at Károli Gáspár University of the Reformed Church in Hungary, Research Centre for the Humanities, Institute of 
History, held a presentation entitled Hadifogolytáborok és (hadi)fogolysors a Kárpát-medencében, 1944-1945 (Political Prisoner Camps and the Destiny of the Prisoners in the Carpathian Basin, 1944-1945), on 29 $9^{\text {th }}$ September 2016. The lecture captivated the audience with contemporary documents, photos, quotes, and a lot of well-illustrated maps.

Erzsébet Molnár D., PhD, Assistant Professor at the Transcarpathian Hungarian Institute 'Ferenc Rákóczi II', Faculty of History and Social Science, researcher of 'Lehoczky Tivadar' Institute, held a very sucessful presentation with the title of Kárpátaljai magyarok és németek szovjet hadifogoly-és kényszermunkatáborokba történó hurcolása (Deportation of Subcarpathian Hungarians and Germans to Soviet War Prisoner and Forced Labour Camps) on $27^{\text {th }}$ October 2016.

The presentation series continues with other interesting works of Attila Árvay, Péter Miklós, PhD, Eleonóra Matkovits-Kretz, and András Majorszki in the following months of the year 2016 and in January-February 2017.

Besides the presentation series, as another project of the memorial year, there is a unique exhibition at Sapientia Hungarian University of Transylvania, Faculty of Sciences and Arts, entitled It Is Easier to Die Than to Separate. The exhibition had a large number of letters written by the prisoners from the labour camps, short, desperate messages that indicated their situation, personal objects and souvenirs from the GULAG/GUPVI lagers. The exhibition was opened by Faculty Dean Professor Márton Tonk and was followed by the lecture of historian Levente Benkő: Foglyok emlékei között. Adalékok a romániai elhurcolások kutatásához (Among the Memories of the Prisoners. Some Aspects to the Research of the Deportations in Romania), while the next lecture was presented by János Kristóf Murádin, PhD, historian, Assistant Professor of the Faculty of Sciences and Arts of Sapientia Hungarian University of Transylvania, with the title of Erdélyi magyarok szovjet fogságban - hét évtized távlatából (Hungarians from Transylvania in Soviet Captivity - from the Perspective of Seven Decades).

Finally, the presentation series Hungarians from Transylvania in Soviet Captivity between 1945 and 1953 gathered approximately an audience of 40-60 at every lecture, bringing back into the collective memory of the people that the GULAG and the GUPVI lagers were a real thing, where a lot of people perished, disappeared, and suffered innocently.

Tímea HORVÁTH

Sapientia Hungarian University of Transylvania Faculty of Sciences and Arts International Relations and European Studies 